\title{
PERBEDAAN FREKUENSI NAFAS SEBELUM DAN SESUDAH LATIHAN PURSED LIP BREATHING PADA PASIEN DENGAN SERANGAN ASMA
}

\author{
Arie Sulistiyawati $^{1 *}$, Yanti Cahyati ${ }^{2}$ \\ ${ }^{1}$ Program Studi D3 Keperawatan, STIKes Dharma Husada Bandung, Jl. Terusan Jakarta No.75, Cicaheum, Kec. \\ Kiaracondong, Kota Bandung, Jawa Barat, Indonesia 40282 \\ ${ }^{2}$ Program Studi Keperawatan, Poltekkes Kemenkes Tasikmalaya, Jl. Babakan Siliwangi No.35, Kahuripan, Kec. \\ Tawang, Tasikmalaya, Jawa Barat, Indonesia 46115 \\ *sulistiyawatiarie@gmail.com (+6281395447685)
}

\begin{abstract}
ABSTRAK
Asma merupakan suatu penyakit yang ditandai dengan obstruksi jalan nafas yang bersifat kambuh berulang dan reversible. Berdasarkan data yang diperoleh dari Rumah Sakit Umum Kota Bandung bahwa di dapatkan data ada 245 orang yang berkunjung ke poli dalam paru dari bulan Januari sampai dengan Desember dengan serangan penyakit asma. Penelitian ini bertujuan untuk membedakan frekuensi nafas sebelum dan sesudah latihan Pursed Lips Breathing pada pasien dengan serangan asma di poli dalam Rumah Sakit Umum Kota Bandung. Jenis penelitian ini merupakan penelitian Quasi eksperiment yaitu dengan Non Equivalent Control Group. Populasi penelitian sebanyak 106, dengan metode pengumpulan data Sampling Purposive, sehingga diperoleh 51 responden. Instrumen dalam penelitian ini menggunakan SOP Latihan Pursed Lips Breathing. Hasil penelitian menunjukan, data sebelum dan sesudah diperoleh nilai Sig. masing-masing sebesar 0,394 dan 0,012 dengan kriteria uji bahwa nilai Sig. lebih besar atau sama dengan nilai alpha $=0,05(5 \%)$ data berdistribusi normal. Frekuensi nafas sebelum dan sesudah latihan pursed lips breathing, di dapati nilai rata-rata frekuensi nafas sebelum sebesar 23,90, dan sesudah 19,94 , didapat perbedaan rata-rata diantaranya keduanya sebesar 3,96 kali, di dapat nilai Z sebesar -6,199 dengan nilai signifikansi (Sig) sebesar 0,00. Kesimpulannya frekuensi nafas sebelum dan sesudah latihan pursed lips breathing pada pasien dengan serangan asma di poli dalam Rumah Sakit Umum Kota Bandung berbeda secara signifikan.
\end{abstract}

Kata kunci: asma; pursed lips breathing

\section{DIFFERENCES BREATH FREQUENCY BEFORE AND AFTER PURSED LIP BREATHING EXERCISES ON PATIENTS WITH ASMA ATTACKS}

\begin{abstract}
Asthma is a disease characterized by recurrent and reversible airway obstruction. Based on data obtained from the General Hospital of Bandung City, it was found that 245 people visited the pulmonary clinic from January to December with asthma attacks. This study aims to distinguish the frequency of breaths before and after the Pursed Lips Breathing exercise in patients with asthma attacks in the General Hospital of Bandung City. This type of research is a Quasi-experimental study, namely the Non Equivalent Control Group. The study population was 106, using purposive sampling data collection method, in order to obtain 51 respondents. The instrument in this study used SOP for the Pursed Lips Breathing Exercise. The results showed that the data before and after the Sig value was obtained. each of 0.394 and 0.012 with the test criteria that the Sig. greater than or equal to the alpha value $=0.05(5 \%)$ data are normally distributed. The frequency of breaths before and after pursed lips breathing exercise, it was found that the average value of the frequency of breaths before was 23.90, and after 19.94, it was found that the average difference between the two was 3.96 times, where the $Z$ value was -6.199 with a significance value (Sig) of 0.00. In conclusion, the frequency of breaths before and after pursed lips breathing in patients with asthma attacks in the General Hospital of Bandung City differed significantly.
\end{abstract}

Keywords: asthma; pursed lips breathing 
Jurnal Penelitian Perawat Profesional, Volume 1 No 1 Hal 121 - 128, November 2019 Global Health Science Group 


\section{PENDAHULUAN}

Asma merupakan suatu penyakit yang ditandai dengan obstruksi jalan nafas yang bersifat kambuh berulang dan reversible. Serangan asma bronchial dapat berupa sesak nafas ekspiratori yang paroksimal berulang - ulang dengan mengi atau wheezing dan batuk yang disebabkan oleh konstriksi atau spasme otot bronkus, inflamasi mukosa bronkus dan produksi lendir kental berlebihan. Bronkus penderita asma sangat peka terhadap rangsangan imunologi maupun non imunologi. Serangan asma mudah terjadi akibat berbagai pemicu, baik fisik, metabolic, kimia, allergen, infeksi dan sebagainya. Oleh karena itu penyebab asma sangat kompleks dan multifaktorial (Masriadi, 2016).

Gejala asma dapat mengalami komplikasi sehingga menurunkan produktifitas kerja dan kualitas hidup (GINA, 2012). Pada penderita asma eksaserbasi akut dapat saja terjadi sewaktu-waktu, yang berlangsung dalam beberapa menit hingga hitungan jam. Semakin sering serangan asma terjadi maka akibatnya akan semakin fatal sehingga mempengaruhi aktivitas penting seperti kehadiran di sekolah, pemilihan pekerjaan yang dapat dilakukan, aktivitas fisik dan aspek kehidupan lain. Gejala asma dapat dikendalikan dengan pengelolaan yang dilakukan secara lengkap, tidak hanya dengan pemberian terapi farmakologis tetapi juga menggunakan terapi nonfarmakologis yaitu dengan cara melatih latihan pernapasan agar dapat mengurangi keparahan gejala asma yang dialami ketika terjadi serangan. (Wong, 2008).

Terapi non farmakologis yang umumnya digunakan untuk pengelolaan asma adalah dengan melakukan terapi pernapasan. Terapi pernapasan bertujuan untuk melatih cara bernapas yang benar, melenturkan dan memperkuat otot pernapasan, melatih ekspektorasi yang efektif, meningkatkan sirkulasi, mempercepat dan mempertahankan pengontrolan asma yang ditandai dengan penurunan gejala dan meningkatkan kualitas hidup bagi penderitanya. Pada penderita asma terapi pernapasan selain ditujukan untuk memperbaiki fungsi alat pernapasan, juga bertujuan melatih penderita untuk dapat mengatur pernapasan pada saat terasa akan datang serangan, ataupun sewaktu serangan asma (Nugroho, 2006).

Salah satu bentuk terapi pernapasan yang dapat diberikan kepada pasien asma adalah latihan Pursed Lips Breathing (PLB). Pursed Lips Breathing merupakan suatu teknik pernapasan, dimana proses ekspirasi dilakukan dengan menahan udara yang dikeluarkan melalui pengerutan bibir dengan tujuan untuk melambatkan proses ekspirasi. Membuat bibir mengerucut seolah-olah meniup lilin, menimbulkan perlawanan melalui saluran udara yang memungkinkan pengosongan paru-paru secara sempurna kemudian menggantikannya dengan udara baru dan segar. Pursed Lips Breathing memungkinkan terjadinya pertukaran udara secara menyeluruh di paru-paru dan memudahkan untuk bernapas, memberikan paru-paru tekanan kecil kembali, dan menjaga saluran udara terbuka untuk waktu yang cukup lama sehingga dapat memeperlancar proses oksigenasi di dalam tubuh. Oksigenasi yang lancar dapat menurunkan kejadian hiperventilasi dan hipoksia pada penderita asma (Pursed Lips Breathing) (Andri, 2014). 
Pursed Lips Breathing merupakan terapi pernapasan yang dapat mengurangi obstruksi pernapasan pada pasien asma. Menurut (Visser, 2011) bahwa Pursed Lips Breathing dapat meningkatkan tekanan intrabronkial selama proses ekspirasi dan mengakibatkan peningkatan diameter bronkial sehingga aliran inspirasi dan ekspirasi menjadi lebih efisien. Tekanan positif intrabronkial mencegah kolaps pada bronki saat ekspirasi sehingga gejala asma seperti sesak napas, batuk, mengi dan rasa tertekan di dada dapat diminimalisir.

Berdasarkan data yang diperoleh dari Rumah Sakit Umum Kota Bandung bahwa di dapatkan data ada 245 orang yang berkunjung kepoli paru dari bulan Januari sampai dengan Desember dengan serangan penyakit asma. Hasil studi pendahuluan yang dilakukan dipoli paru melalui wawancara kepada perawat dinyatakan belum menerapkan Pursed Lips Breathing pada pasien asma. Tindakan umum yang biasanya dilakukan tindakan nebulizer atau pemberian obat bronkodilator. Hasil wawancara yang dilakukan pada 6 orang penderita asma didapatkan bahwa semua pasien memiliki riwayat asma pada keluarganya dan gejalanya seperti timbul batuk - batuk pada pagi hari, siang hari, dan malam hari,sesak napas/susah bernapas, bunyi saat bernapas (whezzing) rasa tertekan di dada, dan gangguan tidur karena batuk atau sesak napas/susah bernapas. Pasien asma juga mengatakan jika asmanya itu kambuh dirumah, pasien hanya beristirahat atau minum obat dan ada juga pasien yang mengatakan jika asmanya itu kambuh pasien langsung mendatangi pelayanan kesehatan seperti rumah sakit. Dan rasa sesaknya itu disebabkan oleh faktor pencetus seperti debu, perubahan cuaca. Keenam penderita penyakit asma tersebut tidak mengetahui tentang latihan Pursed Lips Breathing.

Penelitian ini juga didukung oleh artikel yang dikemukakan oleh Fregonezi, G.A. de F, et al (2004), mengatakan bahwa pursed lips breathing ini memiliki banyak manfaat sebagai salah satu fisioterapi, seperti untuk pasien dengan PPOK, asma, gangguan neuromuskular, atau pun pada pasien yang mengalami gangguan respirasi lainya seperti asma. Sedangkan penelitian menurut (Dechman \& Wilson, 2004) dalam studi Evidence Underlying Breathing Retraining In People With Stable Chronic Obstruktive Pulmonarary Disease menyatakan bahwa Pursed Lip Breathing dapat menurunkan frekuensi nafas, tekanan resistive, mengurangi penyempitan jalan nafas selama ekspirasi dan mengurangi dispnea.

\section{METODE}

Jenis penelitian ini adalah Quasi eksperiment atau eksperimen semu dengan pendekatan Non Equivalent Control Group. Populasi dalam penelitian ini adalah 106 orang pasien asma yang berkunjung ke Poli Dalam Paru pada bulan Januari sampai dengan Desember 2018. Jumlah populasi penelitian yang cukup besar yaitu dengan jumlah sebanyak 106 orang, maka menentukan sampel dalam penelitian ini menggunakan rumus slovin didapatkan 51 orang sebagai sampel dlm peneltian ini.

Metode yang digunakan saat melakukan pengambilan sampel dalam penelitian ini adalah pengambilan sampel dengan sampling purposive dengan kriteria inklusi adalah: Pasien dengan serangan asma dipoli paru, Pasien yang menjalani obat - obatan asma, Pasien yang tidak 
memiliki penyakit gangguan jantung, gangguan neurologic (stroke) dan saraf perifer lain. Kriteria eksklusi adalah: Pasien yang tidak lagi serangan asma (pasien kontrol), Pasien tidak mengikuti terapi yang telah diprogramkan secara penuh dan mengundurkan diri

\section{HASIL}

Tabel 1 diperoleh informasi bahwa dari 51 responden yang diteliti berdasarkan frekuensi nafas sebelum dan sesudah latihan pursed lips breathing pada pasien dengan serangan asma di dalam RSU Kota Bandung, lebih dari setengahnya yaitu 28 orang $(55 \%)$ berjenis kelamin perempuan, responden yang berpendidikan SD 19 (37\%), dan responden yang bekerja $27(53 \%)$.

Tabel 2 dapat dilihat dari nilai uji normalitas frekuensi napas sebelum dengan nilai mean 23,90, sedangkan normalitas frekuensi sesudah dengan nilai mean 19,94, dengan kriteria uji bahwa nilai sig lebih besar atau sama dengan nilai alpa $=0,05 \%$ data berdistribusi normal. Tabel 3 diperoleh rata - rata frekuensi napas sebelum 23,90 kali, dan sesudah didapat nilai rata - rata 19,94 kali dengan sig. 0.00 .

Tabel 1.

Karakteristik Responden Berdasarkan Jenis kelamin, Riwayat Pendidikan dan Pekerjaan

\begin{tabular}{lcc}
\hline \multicolumn{1}{c}{ Jenis Kelamin } & $\mathrm{f}$ & $\%$ \\
\hline Laki - laki & 23 & 45 \\
Perempuan & 28 & 55 \\
\hline Pendidikan & & \\
SD & 19 & 37 \\
SMP & 13 & 25 \\
SMA & 12 & 24 \\
PT & 7 & 14 \\
\hline Pekerjaan & & \\
Tidak Bekerja & 24 & 47 \\
Bekerja & 27 & 53 \\
\hline
\end{tabular}

Tabel 2.

Hasil Uji Normalitas Frekuensi Napas Sebelum dan Sesudah Latihan Pursed Lips Breathing pada Pasien Serangan Asma $(\mathrm{n}=51)$

\begin{tabular}{lll}
\hline Keterangan & $\mathrm{N}$ & Rata - rata \\
\hline Frekuensi napas sebelum & 51 & 23,9 \\
\hline Frekuensi napas sesudah & 51 & 19,94 \\
\hline
\end{tabular}

Tabel 3.

Nilai Rata-rata Frekuensi Napas Sebelum dan Sesudah Latihan Pursed Lips Breathing pada Pasien Serangan Asma

\begin{tabular}{lccccccc}
\hline \multicolumn{1}{c}{ Keterangan } & $\min$ & $\max$ & Rata-rata & Simp. Baku & Z & Sig & Mean Diff. \\
\hline $\begin{array}{l}\text { Frekuensi } \\
\text { napas sebelum }\end{array}$ & 20 & 28 & 23,90 & 1,95 & & & \\
$\begin{array}{l}\text { Frekuensi } \\
\text { napas sebelum }\end{array}$ & 22 & 16 & 19,94 & 1,26 & -6.199 & 0.000 & 3,96 \\
\hline
\end{tabular}




\section{PEMBAHASAN}

Frekuensi Napas Sebelum Latihan Pursed Lips Breathing pada Pasien Dengan Serangan Asma

Hasil data diperoleh dari pola pernapasan pasien asma dapat diketahui bahwa responden sebelum melakukan pursed lips breathing $100 \%$ mengalami pola pernapasan tidak efektif. Didapat nilai rata-rata frekuensi napas sebelum 23,90 dengan nilai sig. lebih besar dari 0.05 maka distribusi bernilai normal dipoli dalam RSU Kota Bandung, dikarenakan terjadi asisosis respiratorik yang disebabkan oleh terperangkapnya udara (air trapping) yang meningkatkan kadar karbondioksida didalam darah. dan gejala asmanya seperti timbul batuk batuk pada pagi hari, siang hari, dan malam hari,sesak napas/susah bernapas, bunyi saat bernapas (whezzing) rasa tertekan di dada, dan gangguan tidur karena batuk atau sesak napas/susah bernapas. Selain itu juga responden mengatakaan asmanya itu diturunkan oleh faktor keluarga, alergi (debu, bulu binatang, serbuk bunga, spora jamur, bakteri dan polusi, obat - obatan, perhiasan, logam).

Penderita asma merupakan gangguan radang kronik saluran napas. Saluran napas yang mengalami radang kronik bersifat hiperresponsif sehingga apabila terangsang oleh factor risiko tertentu, jalan napas menjadi tersumbat dan aliran udara terhambat karena konstriksi bronkus, sumbatan mukus, dan meningkatnya proses radang (Almazini, 2012).

Frekuensi Napas Sesudah Latihan Pursed Lips Breathing pada Pasien Dengan Serangan Asma

Sedangkan setelah dilakukan latihan pursed lip breathing pada pasien dengan serangan asma dipoli dalam RSU Kota Bandung pola pernapasan yang tidak efektif berkurang dengan rata - rata skor pola pernapasan adalah 19,94 setelah diberikan pelakuan. Karena setelah diberikan latihan pursed lip breathing selama 1 kali selama 15 menit, pasien asma mengalami perbaikan pola pernapasan, karena latihan pursed lips breathing ini dapat meningkatkan pengeluaran karbondioksi dan dapat juga meningkatkan jumlah oksigen didalam darah, pursed lip breathing terjadi peningkatan tekanan pada rongga mulut, kemudian tekanan ini akan diteruskan melalui cabang-cabang bronkus sehingga dapat mencegah air trapping dan kolaps saluran napas kecil pada waktu ekspirasi. Ekspirasi yang panjang saat bernafas Pursed Lip Breathing juga akan menyebabkan obstruksi jalan nafas dihilangkan sehingga resistensi pernafasan menurun. Penurunan resistensi pernafasan akan memperlancar udara yang dihirup dan dihembuskan sehingga akan mengurangi sesak nafas.

\section{Perbedaan Frekuensi Napas Sebelum dan Sesudah Latihan Pursed Lips Breathing pada Pasien Dengan Serangan Asma}

Data yang diperoleh dari 51 responden yang diteliti terkait dengan frekuensi nafas sebelum dan sesudah latihan pursed lips breathing pada pasien dengan serangan asma dipoli dalam RSU Kota Bandung, di dapati nilai rata-rata frekuensi nafas sebelum sebesar 23,90 kali dengan simpangan baku sebesar 1,95 kali. Sedangkan rata-rata frekuensi nafas sesudah sebesar 19,94 kali dengan simpangan baku sebesar 1,26 kali.

Hasil rata-rata frekuensi nafas sebelum dan sesudah tersebut didapat perbedaan rata-rata diantaranya keduanya sebesar 3,96 kali di dapat nilai Z sebesar -6,199 dengan nilai signifikansi (Sig) sebesar 0,00 . Karena nilai $Z$ hitung lebih kecil dari $\mathrm{Z}$ tabel $=-1,96$ dan sig. lebih kecil dari 0,05 maka pada tingkat kekeliruan 
5\% diputuskan untuk menolak $\mathrm{H}_{0}$, artinya rata-rata frekuensi nafas sebelum dan sesudah latihan pursed lips breathing pada pasien dengan serangan asma dipoli dalam RSU Kota Bandung berbeda secara signifikan. Hasil ini menunjukkan bahwa pemberian pursed lip breathing berpengaruh secara signifikan terhadap perubahan pola pernapasan.

Latihan pernapasan dengan pursed lips breathing tidak hanya membantu memperbaiki keadaan sesak napas, namun juga dapat membantu seseorang meningkatkan arus puncak ekspirasi, mengurangi frekuensi serangan PPOK, menurunkan tingkat nyeri, menurunkan tekanan darah dan juga memberikan perasaan yang lebih nyaman dan tenang serta dapat memperlambat pola pernapasan saat melakukan latihan. Beberapa gejala mungkin terjadi pada pasien yang mengalami asma seperti batuk - batuk pada pagi hari, siang hari, dan malam hari,sesak napas/susah bernapas, bunyi saat bernapas (whezzing) rasa tertekan di dada, dan gangguan tidur karena batuk. Maka dari itu asma perlu mendapat penanganan secara baik sejak dini sebelum terjadi peningkatan kerusakan paru - paru lebih lanjut.

Melakukan latihan pursed lips breathing membantu menginduksi pola pernapasan lambat, memperbaiki transport oksigen, membantu pasien mengontrol pernapasan dan juga melatih otot respirasi, dapat juga meningkatkan pengeluaran karbondioksida yang disebabkan oleh terperangkapnya karbondioksida karena alveoli kehilangan elastistitas, sehingga pertukaran gas tidak dapat dilakukan dengan maksimal dan meningkatkan ruang rugi di paru-paru, serta membantu mengurangi gejala-gejala atau serangan yang dapat terjadi pada pasien dengan asma seperti sesak napas yang sering dikeluhkan dan menjadi alasan pasien dirawat di rumah sakit, serta menjadi salah satu indikator keberhasilan penatalaksaan pada pasien asma. Latihan pernapasan ini mudah dilakukan sendiri dimanapun oleh penderita asma, tidak ada gerakan yang sulit atau berat, tidak membutuhkan biaya dan tidak memiliki efek samping seperti pada pemakaian obat-obatan. Latihan pernapasan dengan pursed lips breathing ini dapat dilakukan 5 menit atau lebih (smeltzer \& Barre, 2013).

Penelitian ini didukung oleh, hasil penelitian (Dechman \& Wilson, 2004) dalam studi Evidence Underlying Breathing Retraining In People With Stable Chronic Obstruktive Pulmonarary Disease menyatakan bahwa Pursed Lip Breathing dapat menurunkan frekuensi nafas, tekanan resistive, mengurangi penyempitan jalan nafas selama ekspirasi dan mengurangi dispnea.

\section{SIMPULAN}

Frekuensi napas sebelum latihan pursed lips breathing pada pasien dengan serangan asma didapat rata-rata nilai pola pernapasan adalah 23,90 yang berdistribusi normal. Frekuensi napas sesudah latihan pursed lips breathing pada pasien dengan serangan asma didapat pola pernapasan dengan rata rata nilai pola pernapasan adalah 19,94 berdistribusi normal.

Perbedaan frekuensi napas sebelum dan sesudah latihan pursed lips breathing pada pasien dengan serangan asma menunjukkan bahwa pemberian latihan pursed lip breathing berpengaruh secara signifikan terhadap perubahan pola pernapasan didapat perbedaan rata-rata diantaranya keduanya sebesar 3,96 dengan nilai sig. 0,00 kali. 


\section{DAFTAR PUSTAKA}

Aini, F. (2008). Pengaruh Breathing Retraining terhadap Peningkatan Fungsi Ventilasi Paru pada Asuhan Keperawatan Pasien PPOK [serial online]. http://www.jki.ui.ac.id/index.php/j ki/article/viewFile/196/pdf_61.

Astuti, L. W. (2014). Pengaruh Pursed Lips Breathing Terhadap Pola Pernapasa Pada Pasien Dengan Emfisema Di Rumah Sakit Paru Dr. Ario Wirawan Salatiga. http://perpusnwu.web.id/karyailmi ah/documents/3837.pdf.

Andri. (2014). Pengaruh Latihan Pursed Lip Breathing (PBL) terhadap Penurunan Gejala Asma pada Pasien Asma Persisten Ringan dan Sedang di Wilayah Kerja Puskesmas Pauh Padang. Respository.unand.ac.id.

Almazini, P. (2012). Bronchial Thermoplasty Pilihan Terapi Baru untuk Asma Berat.Jakrta: Fakultas Kedokteran Universitas Indonesia

Arikuanto, S. (2010). Prosedur Penelitian. Jakarta: Rineka Cipta

Atmoko. (2011). Prevalens Asma Tidak Terkontrol dan Faktor-Faktor yang Berhubungan dengan Tingkat Kontrol Asma di Poliklinik Asma Rumah Sakit Persahabatan, Jakarta. jurnalrespirologi.org.

Dr. H. Masriadi. (2016). Epidemiologi Penyakit Tidak Menular. Jakarta : CV. Trans Info Media

Dechman \& Wilson. (2004) dalam studi Evidence Underlying Breathing Retraining In People With Stable Chronic Obstruktive Pulmonarary
Disease.

http://ptjournal.apta.org/content/8 4/12/1189.short.

Fiddaroin. (2015). Pengaruh Pursed Lips Brathing terhadap Tingkat Kontrol Asma pada Pasien Asma Di Balai Kesehatan Paru Masyarakat. http://repository.unissula.ac.id.pdf

GINA (Global Initiative for Asthma) (2006). Pocket Guide for Asthma Management and Prevension In Children. www. Dimuat dalam www.Ginaasthma.org.

Khazanah, S. (2014). Efektifitas Posisi Condong Ke Depan (Ckd) Dan Pursed Lips Breathing (Plb) Terhadap Peningkatan Saturasi Oksigen Pasien Penyakit Paru Obstruktif Kronik (PPOK). http://jurnal.unimus.ac.id/index.p hp/psn12012010/article/download /1200/1253.

Laksana. (2016). Faktor - faktor yang Berpengaruh pada Timbulnya Kejadian Sesak Napas Penderita Asma Bronkial. http://jukeunila.com.pdf.

Mawarni. (2015). Profil pasien Asma di Puskesmas Ciputat tengerang Selatan. repository.uinjkt.ac.id.

NANDA. (2015). Asuhan Keperawatan Berdasarkan Diagnosa Medis. Edisi 1. Jogjakarta

Nursalam (2013). Metologi Penelitian Ilmu Keperawatan. Edisi 3. Jakarta: Salemba Medika

Nugroho S, (2006). Terapi pernapasan pada penderita asma. Yogyakarta : Fakultas ilmu keolahragaan universitas negri yogyakarta 
Natalia, (2007). Efektivitas latihan Pursed Lips Breathing dan tiup balon terhadap peningkatan Arus Puncak Ekspirasi (APE) pada pasien asma bronkial rawat inap di RSUD Banyumas. http://digilib.stikesmuhgombong.a c.id/files/disk1/28/jtstikesmuhgogdl dewinatali-1372-2-hal.52-8.pdf.

Potter, P. A., \& Perry, A. G. (2010). Buku Ajar Fundamental Keperawatan. Edisi 7. Singapore : Selemba Medika

Prima. (2012). Bronchial Thermoplasty Pilihan Terapi Baru untuk Asma Berat. www.kalbemed.com.

Smeltzer, S. C., \& Bare, B. G. (2007). Buku Ajar Keperawatan Medikal Bedah. Volume 1. Edisi 8. Jakarta: EGC.

Setiadi. (2007). Konsep dan Penulisan Riset Keperawatan. Jogjakarta: Graha Ilmu.

Purnomo. (2008). Faktor - faktor Resiko yang Berpengaruh terhadap kejadian Asma Bronkial pada Anak. http://eprints.undip.ac.id.pdf.

Widiyani, CTC. (2015). Pengaruh Pursed Lips Breathing Exercise terhadap Arus Puncak Ekspirasi (APE) pada pasien Bronkitis Kronis Di Poli Spesialis Paru. http://repository.Unej.ac.id 